\title{
既存 $\mathrm{RC}$ 梁の外付けせん断補強工法におけるせん断伝達機構 \\ SHEAR TRANSFERRING MECHANISMS OF EXISTING RC BEAMS WITH AN OUTSIDE ATTACHED SHEAR STRENGTHENING METHOD
}

\author{
掛悟史 ${ }^{* 1}$, 倉本 洋*2, Juan Jose CASTRO*3 , 加々良昌史 ${ }^{* 4}$ \\ 樋 渡 健*5, 阿 部 隆 英*6, 久保田 雅春*6 \\ Satoshi KAKE, Hiroshi KURAMOTO, Juan Jose CASTRO, \\ Masashi KAGARA, Takeshi HIWATASHI, Takahide ABE \\ and Masaharu KUBOTA
}

\begin{abstract}
In this study, shear transferring mechanisms of an outside attached shear strengthening method for existing RC beams were examined by three-dimensional FEM analysis. The analytical parameters were cross-section shape, number of connecting anchors, embedded length of anchors and strengthening element width. The analytical results for the shear force versus drift angle relationships showed good agreements with experimental values. The analysis indicated that the arch mechanism is also formed in the strengthening element of the RC beams. Through the analysis it was verified that the effective width of the strengthening element is approximately $75 \mathrm{~mm}$ when the maximum shear force is reached.
\end{abstract}

Keywords : RC beams, Outside strengthening, Shear transferring mechanism, Effective width, FEManalysis $\mathrm{RC}$ 梁, 外付计補強, せん断伝達機構, 補強部有効幅, FEM 解析

\section{1. はじめに}

1995 年の兵庫県南部地震以来, 既存鉄筋コンクリート（以下, RC と略記）造建物に対する而震補強工法が数多く提案されている。そ れらの中には梁および柱のせん断補強工法も含まれているが, 繊維 シートや鋼板を巻き付けたり，コンクリートを増打ちしたりするも のであり, 梁部材の両側面および底面を補強するため建物内部の工 事を伴う場合が多い例え゙ 1),22。一方, 既存 RC 造集合住宅等の場合 には，居住しながらの耐震補強が強く要求されている。

そこで，筆者らは既存 RC 造集合住宅等の梁の外付けせん断補強 工法の開発に着手した。文献 3)では，せん断破壊と判定された梁部 材に対して, 建物外側のみからの簡易な補強を施し, 早期に発生し ていたせん断破壊を遅延させる工法の開発を目的として, 7 体の試 験体を用いた矩形梁の静的載荷実験を実施した。また文献 4)では, 既存梁のせん断余裕度およびスラブの影響の把握を目的として, 9 体の試験体を用いた矩形および $\mathrm{T}$ 形梁の静的載荷実験を実施した。 その結果, 既存 RC 梁に補強を施すことにより, 最大耐力およびせ 几断剛性を上昇させることを示した。また, 補強試験体の終局強度 は学会 RC 規準 ${ }^{5)}$ による既存梁の曲げ終局強度, 既存梁の付着割裂

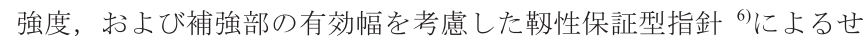
ん断強度のいずれか小さい值で概ね評価できることも示した。

これらの評価において, 補強試験体のせん断強度は既存梁および 補強部のそれぞれのせん断強度を単純累加させることにより算出し た。すなわち，既存梁のせん断強度は勒性保証型指針より求め，補 強部のせん断強度は，既存部位から接続アンカー筋を介してせん断 力が伝達され, 補強部においてアーチ機構が形成されると仮定し, 勒性保証型指針のアーチ機構の項のみを用いて算出した。なお，ア 一チ機構に用いる断面の幅には補強部有効幅として既報 ${ }^{3)}$ で提案し た $75 \mathrm{~mm}$ を用いた。しかし, 補強部のせん断応力伝達メカニズムと してアーチ機構を仮定することが妥当であるか, また応力が伝達さ れる範囲が既報 ${ }^{3)}$ で提案した補強部有効幅 $75 \mathrm{~mm}$ としてよいかにつ いては，合理的に説明するまでには至っていない。

そこで本論文では, 補強 RC 梁の 3 次元非線形 FEM 解析を実施し, FEM 解析の仮定およびモデル化の妥当性を検証する。さらに, 補強 部について変形や応力を直接的に求めることにより，外付け補強を 施した RC 梁の応力伝達メカニズムについて考察する。

\footnotetext{
*1 元 大阪大学大学院工学研究科地球総合工学専攻 大学院生・修士 (工学)

(現 (株)竹中工務店)

*2 大阪大学大学院工学研究科地球総合工学専攻 教授・博士 (工学)

*3 琉球大学工学部環境建設工学科 准教授·博士 (工学)

*4 東亜建設工業(侏)建築事業本部設計部

*5 東亜建設工業株)技術研究開発センター 博士 (工学)

*6 飛島建設(株)建設事業本部卜グル事業部

Former Graduate Student, Div. of Global Architectural, Graduate School of Eng., Osaka Univ., M. Eng.

Prof., Div. of Global Architectural, Graduate School of Eng., Osaka Univ., Dr. Eng.

Assoc. Prof., Dept. of Civil Eng. and Arch., Faculty of Eng., Univ. of Ryukyus, Dr. Eng. Design Department, Architectural Headquarters, Toa Corporation

Research and Development Center, Toa Corporation, Dr. Eng.

Toggle Department, Architectural Business Div., Tobishima Corporation
} 
表 1 試験体諸元

\begin{tabular}{|c|c|c|c|c|c|c|c|}
\hline \multicolumn{2}{|r|}{ 試験体名 } & $\mathrm{A} 1$ & B1-1 & B1-2 & AST & BST-1 & BST-1A \\
\hline \multirow{3}{*}{ 実験変数 } & 既存梁断面形状 & \multicolumn{3}{|c|}{ 矩形 } & \multicolumn{3}{|c|}{ T形 } \\
\hline & 接続アンカー筋本数 & - & 20 (@150mm) & $10(@ 300 \mathrm{~mm})$ & - & \multicolumn{2}{|c|}{$20(@ 150 \mathrm{~mm})$} \\
\hline & 接続アンカー筋埋込み長さ & - & \multicolumn{2}{|c|}{$7 d_{a}(=91 \mathrm{~mm})$} & - & $7 d_{a}(=91 \mathrm{~mm})$ & $12 d_{a}(=156 \mathrm{~mm})$ \\
\hline \multirow{4}{*}{ 既存梁 } & 断面 (mm) & \multicolumn{6}{|c|}{$350 \times 650$} \\
\hline & 主筋 & \multicolumn{6}{|c|}{ 3-D25/2-D22 $\left(\mathrm{p}_{\mathrm{t}}=1.16 \%\right)$} \\
\hline & せん断補強筋 & \multicolumn{6}{|c|}{$\square-D 10 @ 150\left(p_{w}=0.27 \%\right)$} \\
\hline & 内法長さ $(\mathrm{mm})$ & \multicolumn{6}{|c|}{$1,600(\mathrm{a} / \mathrm{d}=1.42)$} \\
\hline \multirow{4}{*}{ 補強部 } & 断面 (mm) & - & \multicolumn{2}{|c|}{$150 \times 650$} & 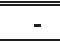 & \multicolumn{2}{|c|}{$150 \times 540$} \\
\hline & 軸筋 & - & \multicolumn{2}{|c|}{ 2-D10 $\left(p_{t}=0.16 \%\right)$} & - & \multicolumn{2}{|c|}{ 2-D10 $\left(p_{t}=0.20 \%\right)$} \\
\hline & あばら筋 & - & \multicolumn{2}{|c|}{$\square-D 10 @ 150\left(p_{w}=0.63 \%\right)$} & - & \multicolumn{2}{|c|}{$\square-D 10 @ 150\left(p_{w}=0.63 \%\right)$} \\
\hline & 内法長さ $(\mathrm{mm})$ & - & \multicolumn{2}{|c|}{$1,500(\mathrm{a} / \mathrm{d}=1.26)$} & - & \multicolumn{2}{|c|}{$1,500(\mathrm{a} / \mathrm{d}=1.55)$} \\
\hline
\end{tabular}

\section{2. 解析対象試験体の概要}

\section{1 試験体概要}

図 1 に解析対象とした試験体の形状および配筋詳細を, 表 1 に試 験体諸元をそれぞれ示す。なお，本論では文献 3）および4）に示され た試験体のうち，最終破壊モードをせん断破壊と判定した試験体の みを対象とした。試験体は実物大で, 無補強試験体 2 体および補強 試験体 4 体の計 6 体である。実験変数は断面形状 (矩形および T形), 接続アンカー筋本数（20 本および 10 本）および接続アンカー筋有 効埋込み長さ $\left(7 \mathrm{~d}_{\mathrm{a}}\right.$ および $12 \mathrm{~d}_{\mathrm{a}}, \mathrm{d}_{\mathrm{a}}$ : 接続アンカー筋径) とした。補 強部はすべての試験体について補強幅を $150 \mathrm{~mm}$ とし, 既存梁のせ ん断耐力の増加のみに寄与させるため両端部に $50 \mathrm{~mm}$ のクリアラン スを設け, 接続アンカー筋により既存梁片面に接続している。なお, 接続アンカー筋には D13 を用い, 定着長さはすべての試験体につい て $6 \mathrm{~d}_{\mathrm{a}}$ とした。

補強試験体の作成は以下の手順で行った。すなわち, 既存梁を打 設した後, 既存梁の片面に先端部が平先寸切状の接続アンカー筋を 注入型の接着系樹脂により固着させた ${ }^{7)}$ 。その後, 補強部と既存梁 の界面での目荒らし処理は行わず，補強部を打設した。なお，既存 梁および補強部の両部位のコンクリートは水平打設とした。

\section{2 材料特性}

表 2 および表 3 にコンクリートの材料特性を，表 4 に鉄筋の材料 特性をそれぞれ示す。既存梁に使用したコンクリートの目標強度は $15 \mathrm{~N} / \mathrm{mm}^{2}$ であり, 補強部に使用したコンクリートの目標強度は $30 \mathrm{~N} / \mathrm{mm}^{2}$ である。既存梁の主筋はSD390を使用し, スラブ筋, 補強 部軸筋, 接続アンカー筋, 既存梁および補強部あばら筋はSD295A を使用した。

\section{3 載荷方法}

図 2 に載荷装置を示す。試験体は反カフレームに PC 鋼棒で固定 し, 水平力の正負繰り返し載荷は反力壁に取り付けたオイルジャッ キ $(2,000 \mathrm{kN})$ によって行った。さらに, 反カフレームに取り付けた 2 台の鉛直オイルジャッキ (各 $2,000 \mathrm{kN}$ ) により, 試験体軸力 $\mathrm{N}=0 \mathrm{kN}$ を保持するように当該ジャッキを制御した。実験では試験体頂部の 水平変位 $(\delta)$ を試験体の内法長さ $(l=1,600 \mathrm{~mm})$ で除した相対部材 角 $\mathrm{R}=\delta / l$ で北側方向を正として制御した。

\section{4 実験結果の概要}

図 3 に無補強試験体のせん断力一部材角関係および補強試験体の せん断力一部材角包絡関係を示し, 図 4 に試験体 B1-1 および BST-1 の最大耐力時における破壊状況を一例として示す。なお, 図 4 中の 灰色部分は補強部を示す。

すべての試験体で, $\mathrm{R}=0.25 \times 10^{-2} \mathrm{rad}$.の載荷サイクルにおいて既存

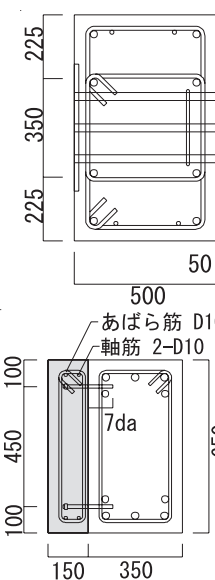

(a) $\mathrm{B} 1-1, \mathrm{~B} 1-2$
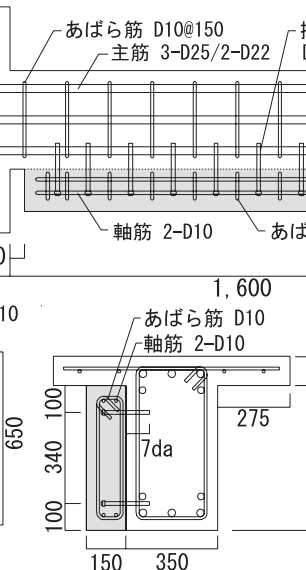

(b) BST-1
図 1 試験体形状および配筋詳細

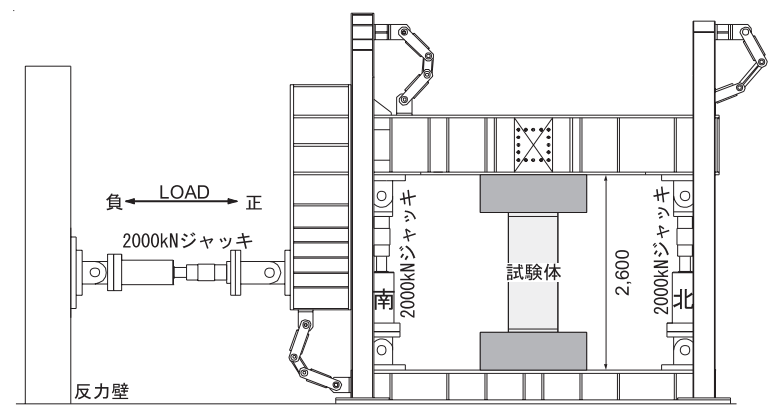

図 2 載荷装置
表 2 既存梁コンクリートの材料特性

\begin{tabular}{c||c|c|c|c|c}
\hline 試験体 & $\sigma_{\mathrm{B}}(\mathrm{MPa})$ & $\varepsilon_{\mathrm{B}}(\mu)$ & $\mathrm{E}_{\mathrm{c}}(\mathrm{GPa})$ & $\sigma_{\mathrm{sp}}(\mathrm{MPa})$ & $\rho\left(\mathrm{kN} / \mathrm{m}^{3}\right)$ \\
\hline \hline $\mathrm{A} 1$ & 13.3 & 1909 & 20.3 & 1.32 & 21.7 \\
\hline $\mathrm{B} 1-1$ & 12.8 & 1819 & 20.5 & 1.88 & 21.6 \\
\hline $\mathrm{B} 1-2$ & 14.2 & 1737 & 22.7 & 1.42 & 21.7 \\
\hline AST & 12.5 & 1970 & 18.8 & 1.36 & 21.5 \\
\hline BST-1 & 14.1 & 1968 & 18.2 & 1.52 & 21.3 \\
\hline BST-1A & 16.1 & 2058 & 21.6 & 1.73 & 21.5 \\
\hline
\end{tabular}

表 3 補強部コンクリートの材料特性

\begin{tabular}{c||c|c|c|c}
\hline 試験体 & $\sigma_{\mathrm{B}}(\mathrm{MPa})$ & $\varepsilon_{\mathrm{B}}(\mu)$ & $\mathrm{E}_{\mathrm{c}}(\mathrm{Gpa})$ & $\sigma_{\mathrm{sp}}(\mathrm{Mpa})$ \\
\hline \hline B1-1 & 33.6 & 1638 & 32.9 & 2.61 \\
\hline B1-2 & 29.9 & 1691 & 29.9 & 2.14 \\
\hline BST-1 & 42.0 & 2173 & 30.2 & 3.21 \\
\hline BST-1A & 43.7 & 2187 & 31.9 & 3.25 \\
\hline
\end{tabular}

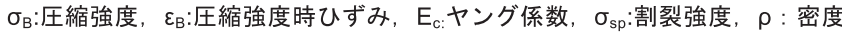

表 4 鉄筋の材料特性

\begin{tabular}{|c|c|c|c|c|}
\hline 種別 & 使用箇所 & $\sigma_{\mathrm{y}}(\mathrm{MPa})$ & $\mathrm{E}_{\mathrm{s}}(\mathrm{GPa})$ & $\sigma_{\mathrm{u}}(\mathrm{MPa})$ \\
\hline D25（SD390） & \multirow{2}{*}{ 既存梁主筋 } & 429 & 188 & 603 \\
\hline D22（SD390） & & 446 & 187 & 621 \\
\hline D13 (SD295A) & アンカー筋 & 340 & 196 & 493 \\
\hline D10 (SD295A) & $\begin{array}{c}\text { スラブ筋 } \\
\text { 補強部軸筋 } \\
\text { あばら筋 }\end{array}$ & 354 & 194 & 506 \\
\hline
\end{tabular}

$\sigma_{\mathrm{y}}$ :降伏点, $\mathrm{E}_{\mathrm{s}}$ :ヤング係数, $\sigma_{\mathrm{u}}:$ 引張強さ 
梁のせん断ひび割れ発生に起因する剛性低下が確認され， $\mathrm{R}=0.5 \sim$ $0.75 \times 10^{-2} \mathrm{rad}$.の載荷サイクルにかけて既存梁せん断補強筋の降伏が 認められた。その後, $\mathrm{R}=0.75 \sim 1.5 \times 10^{-2} \mathrm{rad}$.の載荷サイクルにかけて 最大耐力に達し, 最大耐力点以降は補強部の損傷は大きく進行せず, 既存梁のせん断破壊および付着割裂破壊に伴う緩やかな耐力低下が 確認された。矩形断面の補強試験体の最大耐力は, 無補強試験体 $\mathrm{A} 1$ に対して 1.26 倍（B1-1）および 1.19 倍（B1-2）となった。また， T 形断面の補強試験体の最大耐力は, 無補強試験体 AST に対して 1.16 倍（BST-1）および 1.31 倍（BST-1A）となり, 補強試験体は無補強 試験体に対して約 1.1〜 1.3 倍耐力が上昇した。

接続アンカー筋本数の比較では, 接続アンカー筋本数の多い試験 体 B1-1 の最大耐力は接続アンカー筋本数の少ない試験体 B1-2 と比 べて大きいことが確認された。断面形状の比較では, $\mathrm{T}$ 形梁の最大 耐力は矩形梁の最大耐力と比べて同程度であり, スラブの有無によ る最大耐力の変化は見られなかった。また, 接続アンカー筋埋込み 長さによる比較では, 埋込み長さが深い試験体 BST-1A は R= $1.5 \times 10^{-2} \mathrm{rad}$.の載荷サイクルにおいて最大耐力に達し, 他の試験体と 比べて大きな部材角まで耐力を保持する結果となった。

\section{3. 三次元有限要素解析}

\section{1 解析概要}

解析では前述した 6 体の試験体に加え, 試験体 B1-1 のシアスパン 比を 1.0 および 2.0 に変化させた解析モデル B1-1(a/D1.0)および B1-1(a/D2.0), および試験体 BST-1A の補強幅を 250mm まで増加さ せた解析モデル CST-1A の 3 体も対象とした。表 5 に試験体の解析

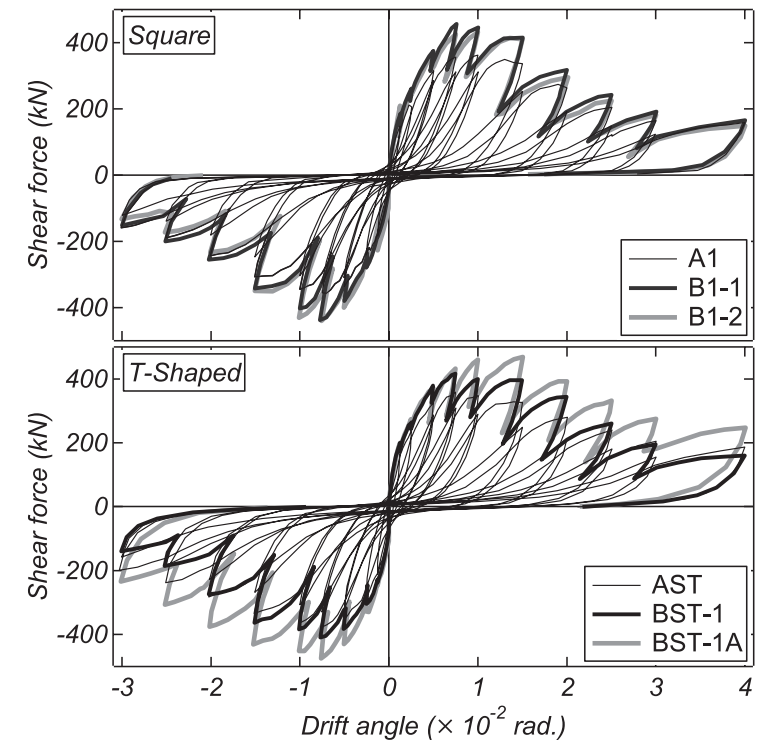

図 3 世九断力一部材角包絡関係

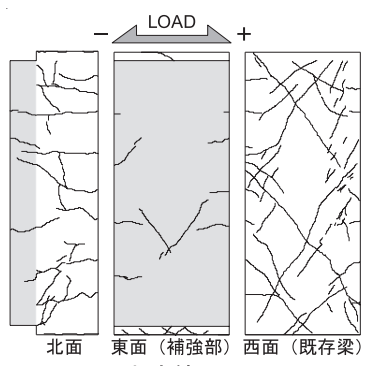

(a) 試験体 B1-1

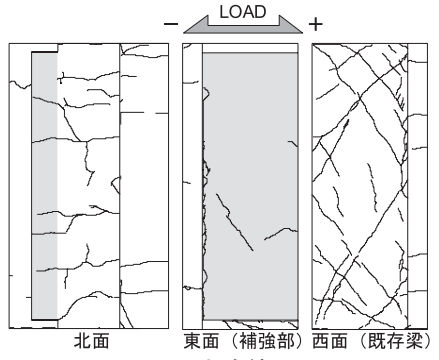

(b) 試験体 BST-1
図 4 最大耐力時ひび割れ状況一例
変数を示す。

図 5 に試験体の要素分割を示し, 図 6 に試験体 B1-1, B1-2 および BST-1A の梁断面の解析モデル詳細を一例として示す。各要素は, 試験体の主筋，スラブ筋，軸筋，および接続アンカー筋の配筋位置 に準じて分割した。加力はスタブ下端において試験体に作用する軸 力 $\mathrm{N}=0 \mathrm{kN}$ を保持し, スタブ上端に実験と同じ部材角となるよう強制 変位を与えた。本解析では変位制御による正負交番繰り返し載荷と し, 解析モデル B1-1(a/D2.0)では $\mathrm{R}=1.0 \times 10^{-2} \mathrm{rad}$. 以降で,その他の試験 体では $\mathrm{R}=1.5 \times 10^{-2} \mathrm{rad}$. 以降で解析結果が不安定になったため, その時 点で計算を終了した。なお, 解析は 3 次元非線形解析ソフト $「$ FINAL $^{8)} 」 を$ 用いて行った。

3.2 コンクリートモデル

コンクリートは 8 節点アイソパラメトリック立体要素でモデル化 し, 既存梁および補強部ともに共通の材料構成則を仮定した。本解 析では既存梁および補強部のコンクリートについて，あばら筋によ り拘束された要素（以下，コアコンクリートと呼称）とかぶり要素 (以下，カバーコンクリートと呼称）を異なる材料構成則により定 義した。応力ーひずみ関係については, 圧縮側の応力上昇域および 軟化域は修正 Ahmad モデル ${ }^{9}$ (図 7 (a) 参照) とした。三軸応力下

表 5 解析変数

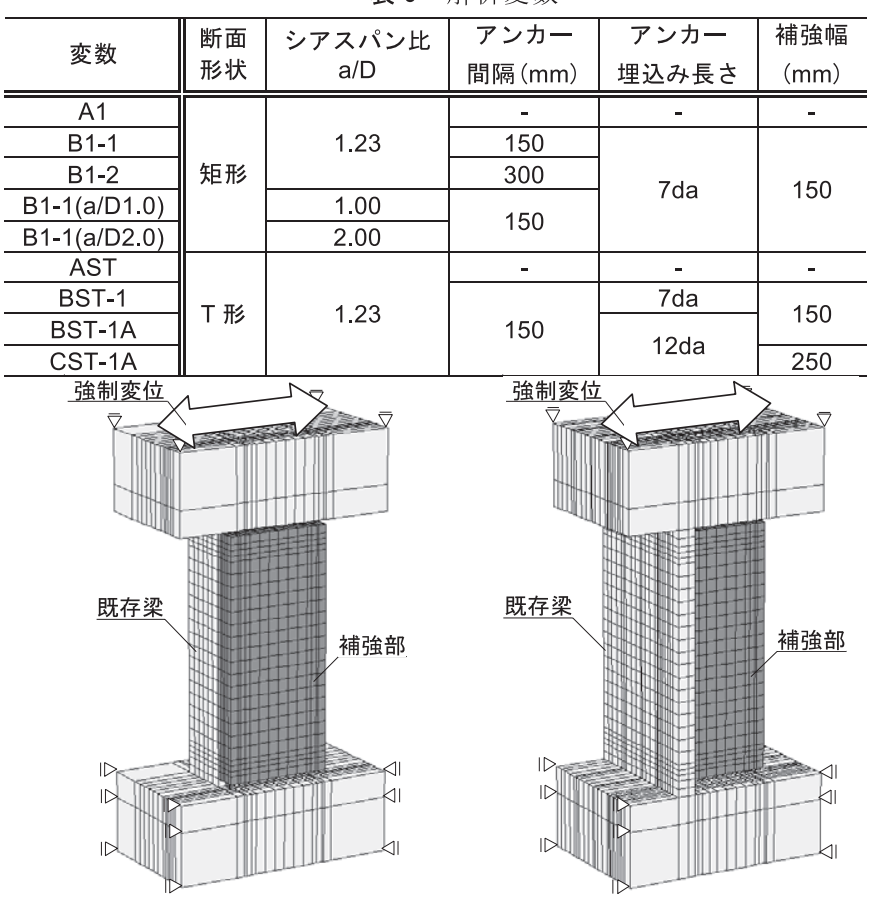

(a) 矩形断面

(b) $\mathrm{T}$ 形断面

図 5 要素分割

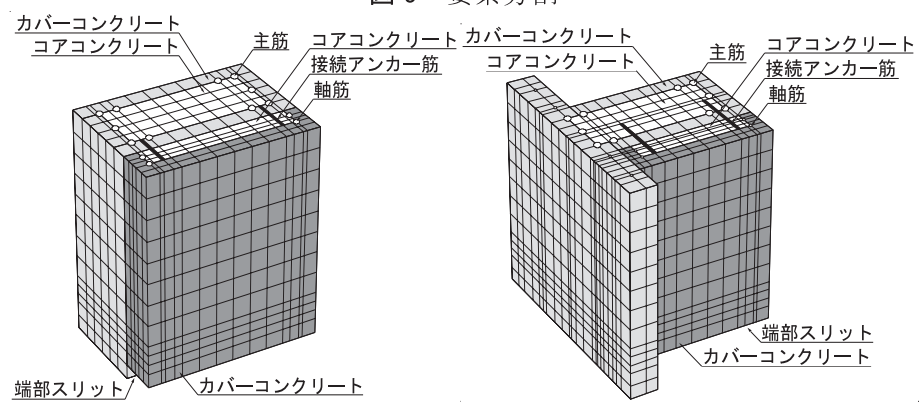

(a) 試験体 B1-1，B1-2

(b) 試験体 BST-1A

図 6 梁モデル断面詳細一例 
の圧縮破壞条件は，コアコンクリートにおいてはあばら筋による拘 束効果を考慮して Ottosen の 4 パラメータモデルに畑中らの係数 ${ }^{10)}$ を採用したものを適用した。カバーコンクリートは, 拘束効果を考 慮せず一軸圧縮強度まで到達すると仮定した。引張側についてはひ び割れ発生点までは線形で，ひび割れ後のテンションスティフニン グ特性は出雲らのモデル ${ }^{11}$ （図 7（b）参照）を適用し, 係数はコア コンクリートを $\mathrm{C}=0.4$, カバーコンクリートを $\mathrm{C}=1.0$ とした。コン クリートの繰り返し応力下の履歴特性は除荷と再載荷過程における 軟化挙動を考慮した曲線モデル ${ }^{12}$ ) (図 7 (c) ) を使用した。ひび割 れ後のせん断伝達モデルには Al-Mahaidi モデル ${ }^{13)}$ (図 7 (d) ) を適
用した。

本論では, 乾燥収縮ひび割れ等の初期ひび割れによる剛性低下を 考慮するため, 䩚性保証型指針 ${ }^{6}$ を参考にして既存梁コンクリート のヤング係数 $E_{c}$ を下式により修正し, 既存梁コンクリートの引張強 度 $\sigma_{s p}$ は下式 6) を用いて算定した。既存梁コンクリートの圧縮強度, 圧縮強度時ひずみおよび補強部コンクリートの各值については材料 試験結果を用いた。なお, 解析モデル B1-1(a/D1.0)およびB1-1(a/D2.0) のコンクリートの諸值は試験体 B1-1 と同様とし,解析モデル CST-1A の諸值は，試験体 BST-1A と同様の值を設定した。

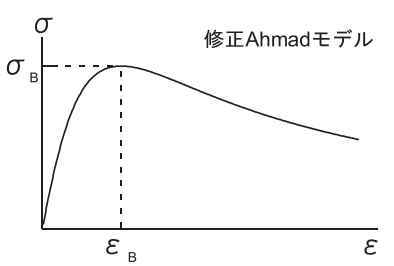

（a）圧縮側応カーひずみ関係

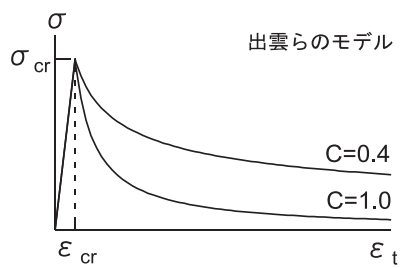

(b) 引張側応カーひずみ関係

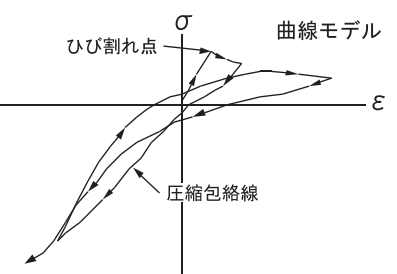

（c）履歴特性

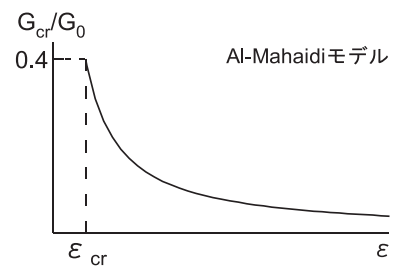

（d）ひび割れ後のせん断伝達特性

図 7 コンクリートの材料構成則

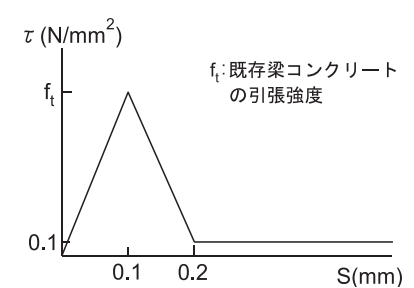

図 8 接合面における固着応力ー相対すべり関係

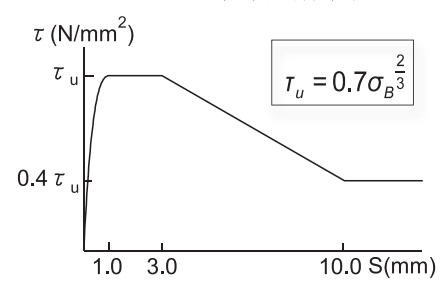

(a) 主筋・軸筋・アンカー定着䚋

図 9 鉄筋とコンクリートの

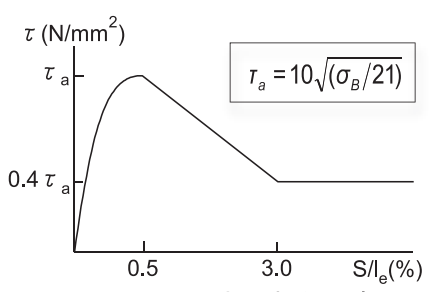

(b) アンカー埋込み側
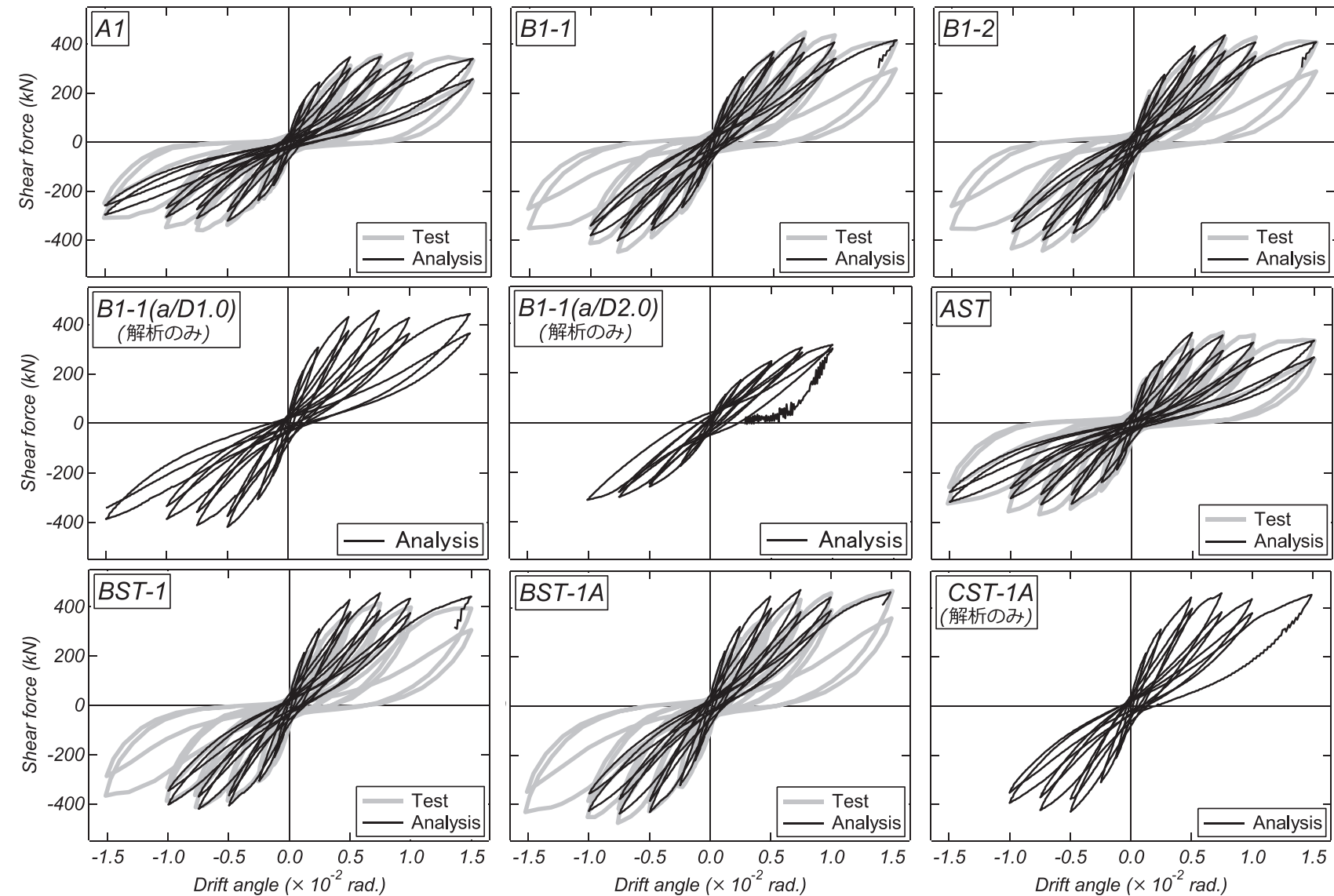

図 10 実験および解析におけるせん断力一部材角関係 


$$
\begin{aligned}
& E_{c}=21000 \times\left(\frac{\rho}{23}\right)^{1.5} \times \sqrt{\frac{\sigma_{B}}{20}} \quad\left(\mathrm{~N} / \mathrm{mm}^{2}\right) \\
& \sigma_{s p}=0.33 \sqrt{\sigma_{B}} \quad\left(\mathrm{~N} / \mathrm{mm}^{2}\right)
\end{aligned}
$$

また，本実験では補強部コンクリート打設の際に，既存梁コンク リート表面に目荒らし処理は行っていない。しかし, 接続アンカー 筋による接合面には目荒らしを行っていない場合においても,コン クリートの引張強度と同程度の固着力が発生し, 最大固着応力後は 固着による抵抗力は急激に低下するが, 接続アンカー筋のダボ作用 による効果が期待できることが知られている ${ }^{14)}$ 。そこで, 本解析で は実験同様，既存梁および補強梁の界面のずれを表現するため，既 存梁と補強部の間に離散ひび割れ要素を使用し，せん断伝達特性と して図 8 に示寸接合面の固着特性を考慮した。なお, 固着強度には 既存梁コンクリートの引張強度を設定した。また垂直方向（試験体 面外方向）の特性は, 両者が密着寸る方向には応力を伝達し, 離間 する方向には応力を伝達しないように接合要素の特性を定義した。

\section{3 鉄筋および接続アンカー筋モデル}

既存梁主筋および補強部軸筋はトラス要素でモデル化し, 既存梁 および補強部のせん断補強筋については埋め込み鉄筋として六面体 要素内に層状置換し，コンクリート要素に対する鉄筋比として入力 した。また，接続アンカー筋は曲げ変形およびせん断変形を考慮で きる円形中実断面の積層シェル要素によりモデル化し, ダボ効果を 表現した。鉄筋の応力ーひずみ関係はバイリニアモデルとし, 履歴 特性は修正 Menegotto-Pinto モデル ${ }^{15)} と し$, 材料定数は材料試験結果
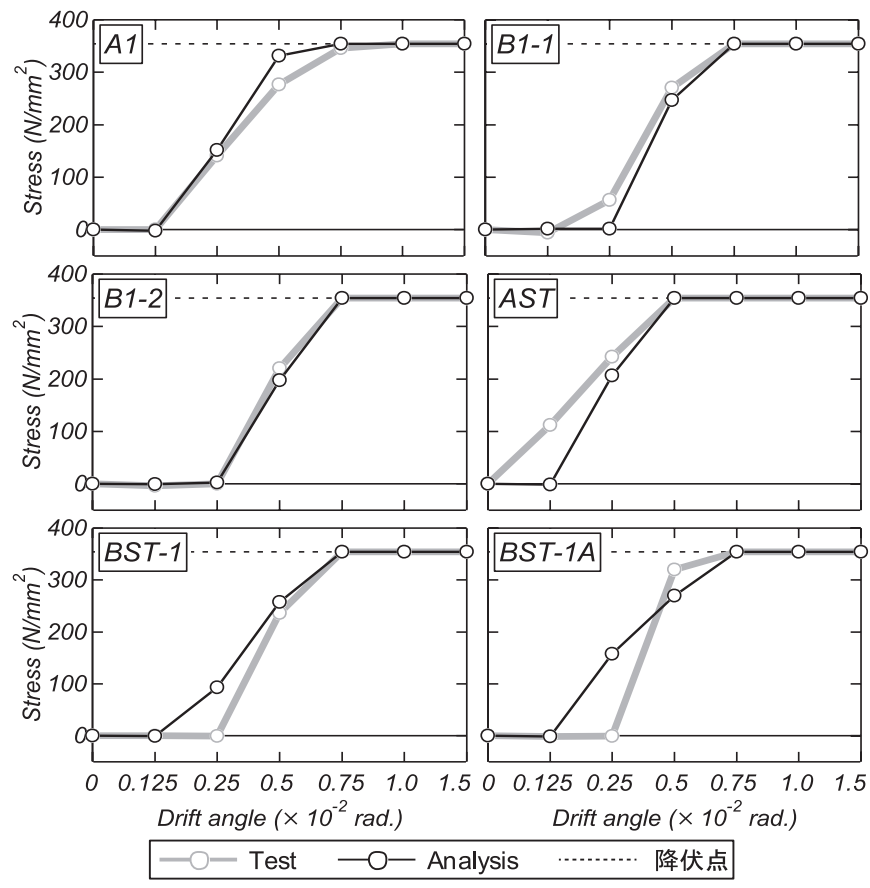

図 11 実験および解析における既存梁あばら筋応力一部材角関係

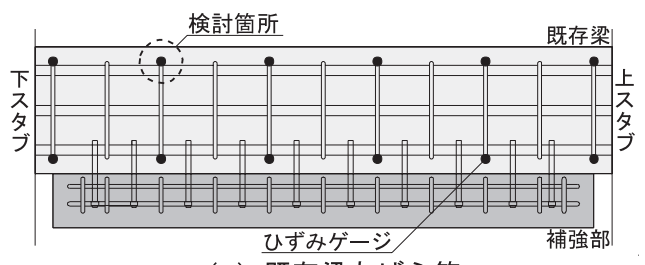

(a) 既存梁あばら筋

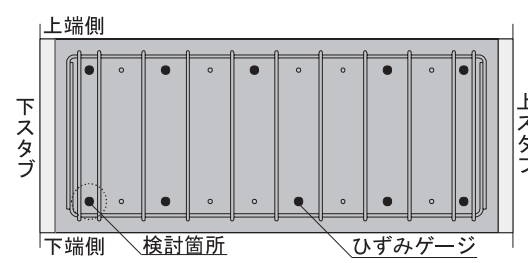

(b) 接続アンカ一筋
また，既存梁主筋，スラブ筋，補強部軸筋および接続アンカー筋 定着側・埋込み側とコンクリートとの間での付着す心゙りを考慮する ため,鉄筋要素とコンクリート要素の節点間に接合要素を挿入した。 既存梁主筋，スラブ筋，補強部軸筋および接続アンカー筋定着側の 付着応力ー相対すべり関係は, CEB/FIP Model Code 1990 $0^{16}$ により図 9 (a) の曲線のように設定し, 最大付着応力 $\tau_{u}$ は耐震性能評価指針 ${ }^{17)}$ より算出した。また，接続アンカー筋の埋込み側の付着応力一相 対すべり関係は文献 18)より，図９（b）の曲線のように設定し，最 大付着応力 $\tau_{a}$ は耐震改修設計指針 ${ }^{7)}$ より算出した。

\section{4. 解析結果}

\section{1 履歴特性}

表 6 に各試験体の実験值と解析值の最大耐力值の比較を示し, 図 10 に実験および解析におけるせん断力一部材角関係を示す。

解析結果より, 寸心゙ての試験体で履歴性状は実験結果と比べて原 点を指向する傾向が認められた。矩形断面試験体では, 負載荷側の 最大耐力の解析值は実験值と比べて小さくなる傾向が見られたが, 最大耐力までの剛性および正載荷側の最大耐力の解析值は実験值と 概ね一致しており，各変形角の第 2 サイクルおよび $\mathrm{R}=1.5 \times 10^{-2} \mathrm{rad}$. までの耐力低下も精度良く再現できている。 $\mathrm{T}$ 形断面試験体では, 補強試験体において $\mathrm{R}=0.5 \times 10^{-2} \mathrm{rad}$.の正載荷までの解析の耐力は実 験值と比べて大きくなる傾向が認められたが，正負両載荷の最大耐

表 6 実験值および解析值における最大耐力值の比較

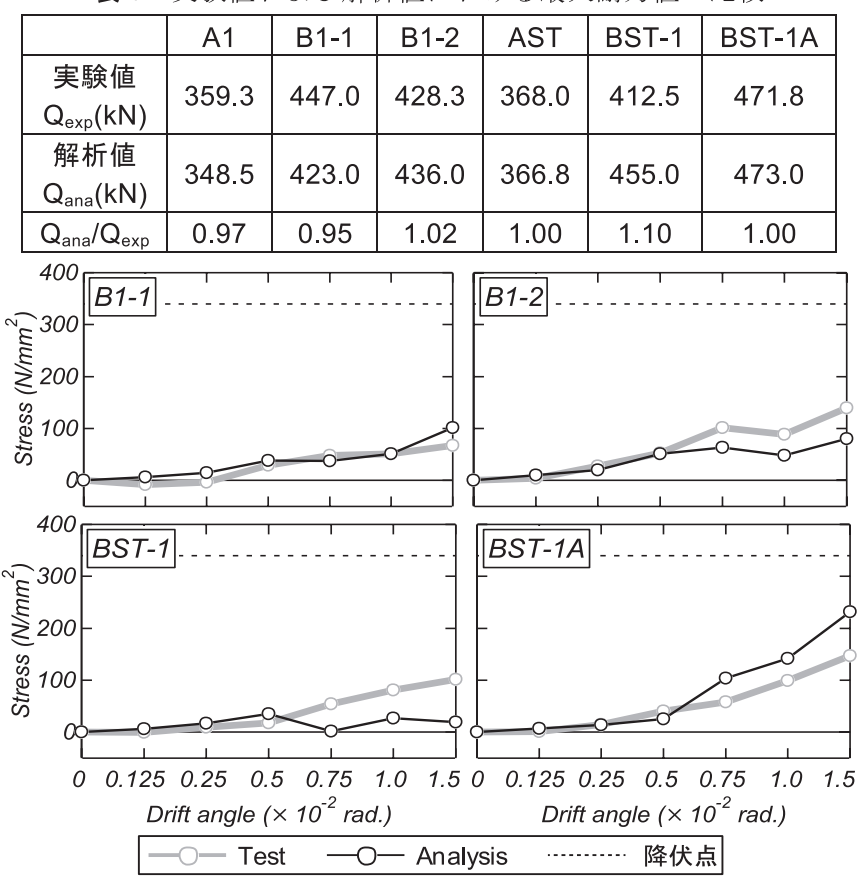

図 12 実験および解析における接続アンカー筋応力ー部材角関係

図 13 ひずみゲージ貼付位置

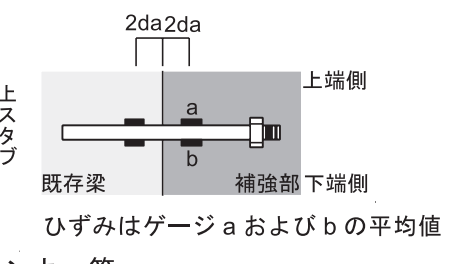

ひずみはゲージ a および b の平均値 
力の解析值は実験值と概ね一致しており, 矩形断面試験体同椂, 各 変形角の第 2 サイクルおよび $\mathrm{R}=1.5 \times 10^{-2} \mathrm{rad}$.までの耐力低下も精度 良く再現できている。

また, 解析モデル B1-1(a/D1.0)は試験体 B1-1 と同様の履歴性状を 示したが，最大耐力が $456 \mathrm{kN}$ となり試験体 B1-1 と比べて大きくな る傾向が確認された。解析モデル B1-1(a/D2.0)では, 初期剛性およ び最大耐力值が試験体 B1-1 と比べて小さくなり, 曲げ降伏型の履歴 性状を示した。さらに, 解析モデル CST-1A では, 正負両載荷の最 大耐力は試験体 BST-1A と同程度となり, 履歴性状についても試験 体 BST-1A とほぼ同様になる結果となった。

\section{2 鉄筋ひずみ}

図 11 に $\mathrm{R}=1.5 \times 10^{-2} \mathrm{rad}$.までの実験と解析における既存梁あばら筋 応力一部材角関係を示し, 図 12 に $\mathrm{R}=1.5 \times 10^{-2} \mathrm{rad}$.までの接続アンカ 一筋応力ー部材角関係を示寸。既存梁あばら筋および接続アンカー 筋応力は, 鉄筋の履歴特性をバイリニアと仮定し, ひずみゲージ (図 13 参照）から得られた測定値を用いて計算した。

既存梁あばら筋では, 応力発現時の部材角は解析結果と実験結果 にばらつきが見られた。しかしながら, 応力発現以降の部材角にお いては, あばら筋応力の解析結果は実験結果と概致おり, あば ら筋降伏時の部材角についても, 精度良く再現できている。接続ア

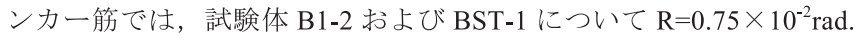
以降の解析結果は実験結果と比べて小さくなる傾向が見られた。し かしながら, 解析結果は実験結果同様, 弾性域内に留まっており, 各部材角における接続アンカー筋応力の解析結果は実験結果と概衩 一致している。なお, 図 11 および図 12 には一部の結果の夕示して いるが，その他の計測位置についても解析結果は実験結果と概ね一 致している。

以上の解析結果から, 本解析モデルにおいて RC 梁の履歴特性は $\mathrm{R}=1.5 \times 10^{-2} \mathrm{rad}$. な゙概初模擬できたと判断し, 次章からは本解析結 果を用いて RC 梁の内部応力状態について検討を進める。

\section{5. 内部応力状態}

\section{1 最小主応力分布}

図 14 に $\mathrm{R}=0.75 \times 10^{-2} \mathrm{rad}$.の 1 サイクル目正載荷ピーク時における各 切断面の最小主応力分布 (圧縮応力分布) を示す。なお解析結果に おいて, すべての試験体で同様な傾向が見られたため, 図 14 は試験 体 A1，B1-1，AST および BST-1 のみを示す。

無補強試験体 A1 および AST では，いずれの切断面においても一 端から他端（図中の上端から下端）にかけて圧縮ストラットが明確 に形成されており, 圧縮側端部に高い圧縮応力が生じている。一方, 補強試験体 B1-1 および BST-1 では, 切断面 1 では無補強試験体同 様, 一端から他端にかけて圧縮ストラットが明確に形成されており, 圧縮側端部に高い圧縮応力が生じている。しかしながら, 切断面 2 では, 切断面 1 のような明確な圧縮ストラットが形成されておらず, 切断面上で応力が分散していることが確認できる。また切断面 3 で は, 補強部において接続アンカー筋を介して圧縮ストラットが形成 されていることが確認できる。その分布は界面から面外方向に離れ ていくにつれて補強部端部の圧縮応力が小さくなっており, 補強部 において立体的なアーチ機構を形成していることがわかる。

以上の考察を踏まえて, 補強試験体における応力伝達メカニズム
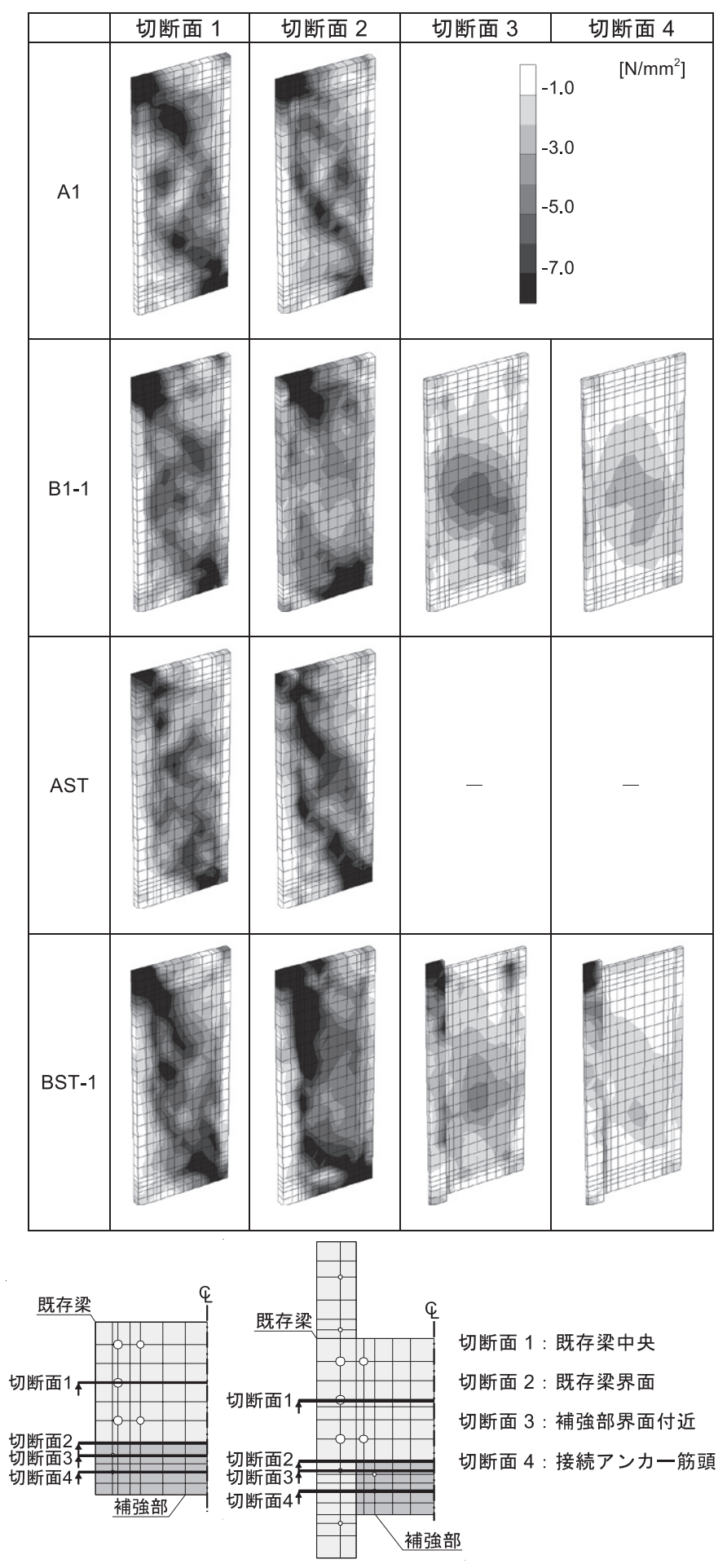

図 14 最小主応力分布 $\left(\mathrm{R}=0.75 \times 10^{-2} \mathrm{rad}\right.$.ピーク時 $)$

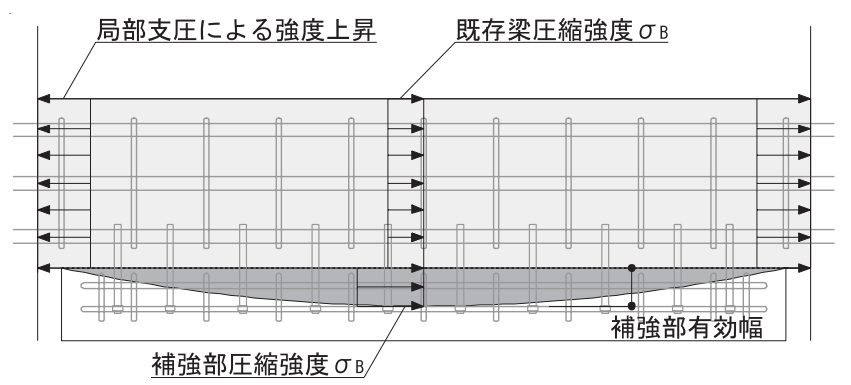

図 15 補強試験体破壊メカニズム 
の概念図を図 15 に示す。同図に示すように, 既存梁のコンクリート 忘力が梁中央部で圧縮強度に達したとき, 補強部のコンクリート応 力も有効幅の範囲で中央部において圧縮強度に到達するものとして 立体的なアーチ機構を仮定した。なお，この場合部材端部では局部 支圧による応力上昇が生じていると仮定し, 部材中央部の圧縮強度

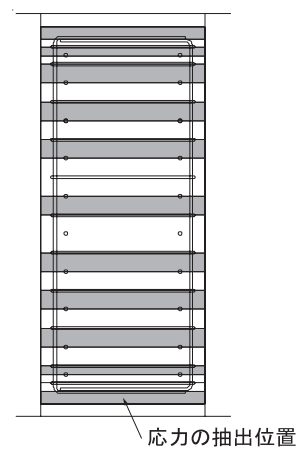

(a) 矩形断面

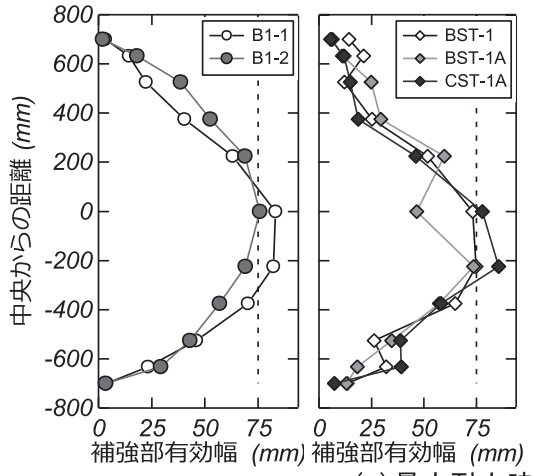

(a) 最大耐力時

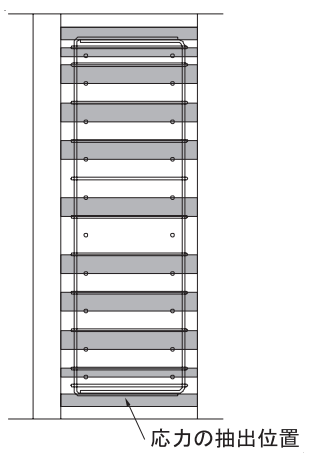

(b) $\mathrm{T}$ 形断面
図 16 コンクリートの要素位置

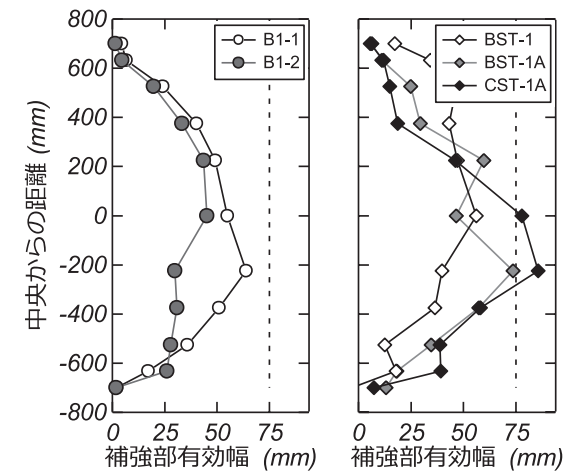

(b) $R=1.5 \times 10^{-2} \mathrm{rad}$. ピーク時

図 17 補強部有效幅分布

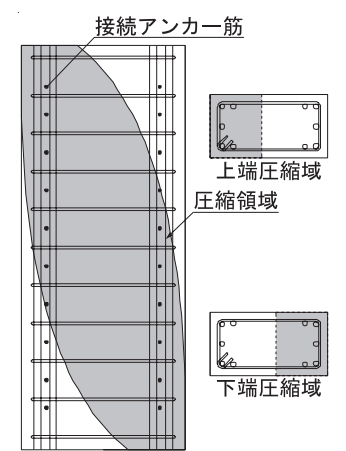

(a) 矩形断面

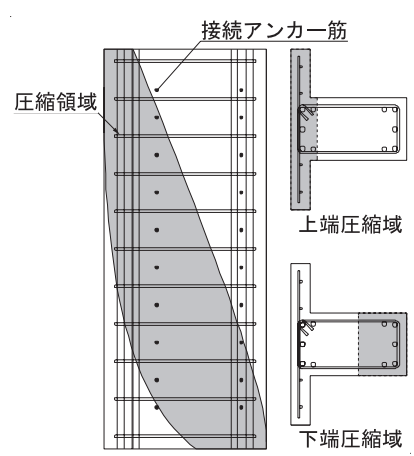

(b) T 形断面

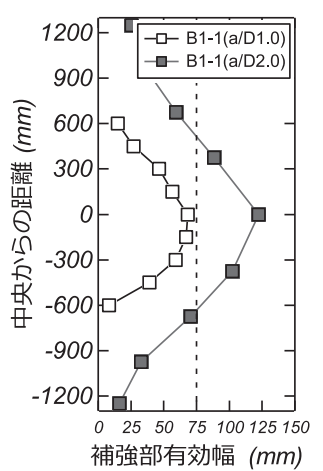

補強部有効幅 $(\mathrm{mm})$

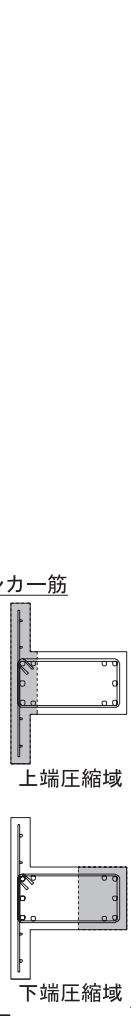

図 18 既存梁の圧縮ストラット形状モデル
と補強による有効幅を用いて勒性保証型指針を適用することとした。

\section{2 補強部有效幅の推移}

図 16 にコンクリートの要素位置を示し, 図 17 に最大耐力時およ び $\mathrm{R}=1.5 \times 10^{-2} \mathrm{rad}$.ピーク時における補強試験体の補強部有効幅の分 布を示す。図 17 中には既報 ${ }^{3)}$ で提案した有効幅 $75 \mathrm{~mm}$ を併せて示す。 5.1 節でも述べたように, 既存梁から補強部へは複数の接続アン カー筋により応力が伝達されているため, 部材中央部付近でコンク リートの圧縮応力が最大となるものと仮定した。そこで，この仮定 の妥当性ならびに部材中央部における補強部の有効幅の検討を行う。

補強部有効幅 $b_{e}$ は図 16 に示寸要素位置における補強部分の負担 せん断力 $V_{u}$ を用いて下式より算出した。なお，下式は勒性保証型指 針 ${ }^{6}$ のアーチ機構の項を変形したものである。

$$
b_{e}=\frac{2 V_{u}}{v \sigma_{B} D \tan \theta}
$$

ここで, $\quad v$ は補強部コンクリート圧縮強度の有効係数, $\sigma_{B}$ は補強 部コンクリートの圧縮強度, $D$ は梁せい, $\tan \theta$ はアーチ機構の圧縮 束角度 $(=0.9 \times \mathrm{D} / 2 \mathrm{~L}, \mathrm{~L}$ : 補強部内法長さ) である。なお, 補強部 への応力伝達は接続アンカー筋および界面での固着力によるものが 考えられるため, $\tan \theta$ は固着力が作用する補強部の形状とした。

図 17 より,す心゙ての補強試験体において最大耐力時の補強部有効 幅の最大值は，部材中央部付近で $75 \mathrm{~mm}$ 付近に分布していることが 見てとれる。また図 17 より， $\mathrm{R}=1.5 \times 10^{-2} \mathrm{rad}$.のピーク時における各 試験体の有効幅の最大值の比較では, 接続アンカー筋本数の少ない 試験体 B1-2 の補強部有効幅は, 接続アンカー筋本数の多い試験体 B1-1 と比べて小さく, また接続アンカー筋埋込み長さが浅い試験体 BST-1 の補強部有効幅は, 埋込夕長さが深い試験体 BST-1A および 解析モデル CST-1A と比べて小さくなる傾向が認められる。また補 強幅の比較では, 解析モデル CST-1A の補強部有効幅は試験体 BST-1A と同程度であり, 最大耐力も同程度であることから補強幅 を増加させたことによる補強増大効果は認められない。このことは 文献 3)の矩形断面試験体でも同様な傾向が確認されている。

また, 最大耐力時における補強部有効幅の分布形状について, $\mathrm{T}$ 形断面試験体では矩形断面試験体と比べて補強部上端の有效幅が小 さくなっていることが見てとれる。これは図 18 の既存梁の圧縮ス卜 ラット形状モデルに示寸ように，T 形断面ではスラブが圧縮される 既存梁上端において, スラブ全体で圧縮力を負担するため, 既存梁 の圧縮ストラット上端の幅は細くなり，接続アンカー筋を介して補 強部に作用するせん断力が小さくなるためと考えられる。

さらに, シアスパン比の変化における最大耐力時の補強部有効幅 の比較では, 解析モデル B1-1(a/D1.0)の有効幅は $68 \mathrm{~mm}$ となり, $75 \mathrm{~mm}$ に到達していないことが確認された。一方, 解析モデル B1-1(a/D2.0)の有効幅は $122 \mathrm{~mm}$ となっており，75mm を大幅に上回 る結果となっている。しかしながら, B1-1(a/D2.0)の破壊モードは曲 げ降伏先行型となっているため, その影響も考慮する必要があろう。

以上のことから, シアスパン比が $\mathrm{a} / \mathrm{D}=1.23$ の試験体について, せ 儿断破壊型の補強試験体の最大耐力時において, 補強部有効幅の最 大值は部材中央部付近で $75 \mathrm{~mm}$ 程度となっていることが確認された。 また, 接続アンカー筋埋込み長さが深いほど, および接続アンカー 筋本数が多いほど補強部が負担するせん断力は大きくなるが, 補強 部の幅を大きくしてもせん断耐力の増加はほとんど期待できないと 
いえる。さらに，スラブの有無による既存梁の圧縮ストラットの形 状の違いにより補強部のせん断伝達機構に差異あることなども併せ て確認された。なお, シアスパン比が大きくなるほど補強部有効幅 が大きくなる傾向も確認されたが，これに関しては実験等も含めた より詳細な検討が必要であり, 今後の課題としたい。

\section{6. まとめ}

本論では, 外付け補強を施した矩形および $\mathrm{T}$ 形 $\mathrm{RC}$ 梁の 3 次元非 線形 FEM 解析を実施し, 解析モデルの妥当性の検討, $\mathrm{RC}$ 梁のせん 断伝達機構および実験変数が補強部のせん断伝達機構に及ぼす影響 について検討を行った。本研究より得られた知見を以下に示す。

1) 補強 RC 梁の挙動は本論で提案した 3 次元 FEM 解析モデルによ って概ね再現することができる。

2) 補強 RC 梁では, 既存梁の断面形状, 接続アンカー筋の本数お よび埋込み長さに関係なく, 接続アンカー筋を介して既存梁か ら補強部に立体的なアーチ機構が形成される。

3) 補強部有効幅は最大耐力時において, 既報で提案した $75 \mathrm{~mm}$ 付 近に分布する。また，接続アンカー筋埋込み長さが深いほど, および接続アンカー筋本数が多いほど補強部のせん断耐力は 大きくなるが，補強部の幅を大きくしてもせん断耐力の増加は ほとんど期待できない。

4) $\mathrm{T}$ 形断面を有寸る補強 RC 梁では, 既存梁スラブが圧縮力を負 担するため，矩形断面を有する $\mathrm{RC}$ 梁と比べて有効幅が最大と なる位置が中央部からスラブ圧縮端とは逆方向に移行する傾 向がある。

5) 補強 RC 梁のシアスパン比が大きくなるほど補強部有効幅が大 きくなる傾向があるが，この影響に関しては実験等も含めたよ り詳細な検討が必要である。今後の課題としたい。

\section{謝辞}

本研究の一部は, 国土交通省「平成 $23 \cdot 24$ 年度住宅・建築関連先 導技術開発助成事業」の助成を受けて東亜建設工業, 飛島建設およ び大阪大学の 3 機関により共同で実施した。また梁補強実験の実施 および解析実施にあたり, 元大阪大学の前田敦志氏 (現 (株) 奥村組) および大阪大学大学院生の倉本真氏ならびに鈴木卓氏の協力を得た。 ここに記して謝意を表します。

\section{参考文献}

1）帆足勇磨，増田安彦，田才晃，楠浩一：低強度コンクリート $\mathrm{RC}$ 構造物の 付着性状および炭素繊維シート補強効果に関する実験的研究, コンクリー 卜工学年次論文集, 第 31 巻, 第 2 号, pp.1003-1008, 2009

2）大石祐太，三島直生，畑中重光：低強度コンクリートを用いた RC 梁の破 壞挙動とCFRPによる補強効果に関する研究, 日本建築学会大会学術講演 梗概集, C-2, 構造IV, pp.639-640, 2010

3）掛悟史, 阿部隆英, 加々良昌史, 倉本洋 : 既存梁部材の外側せん断補強工 法の開発, コンクリート工学年次論文集, 第 34 巻, 第 2 号, pp.1027-1032, 2012

4）倉本真，掛悟史，加々良昌史，樋渡健，阿部隆英，久保田雅春，カストロ ホワン ホセ, 倉本洋 : スラブ付き $\mathrm{RC}$ 梁に対するせん断破壊遅延型補強 工法に関する研究, 日本建築学会近畿支部研究発表会, 第 53 号, 構造 系,pp.309-312, 2013.6

5）日本建築学会 : 鉄筋コンクリート構造計算規準・同解説， 2010

6）日本建築学会 : 鉄筋コンクリート造建物の勒性保証型設計指針・同解説, 1997

7）（財）日本建築防災協会：2001 年改訂版 既存鉄筋コンクリート造建築物 の耐震改修設計指針・同解説, 2001.10

8）伊藤忠テクノソリューションズ（株）：FINAL/V11 HELP, 2010.3

9）長沼一洋：三軸圧縮下のコンクリートの応力〜ひずみ関係，日本建築学会 構造系論文集，第 474 号, pp.163-170, 1995.8

10）水野英二, 畑中重光：塑性理論によるコンクリートの圧縮軟化特性のモ デル化, コンクリート工学年次論文集, 第 2 巻, 第 2 号, pp.85-95, 1991.7

11）出雲淳一他：面内力を受ける鉄筋コンクリート板要素の解析モデル，コ ンクリート工学論文, No.87.9-1, pp.107-120, 1987.9

12）長沼一洋，大久保雅章：繰返し応力下における鉄筋コンクリート板の解 析モデル, 日本建築学会構造系論文集, No.536, pp.135-142, 2000.10

13) Al-Mahaidi, R.S.H. : Nonlinear Finite Element Analysis of Reinforced Concrete Deep Members, Report 79-1, Dep.of Structural Engineering, Cornell Univ., 1979.1

14）榎本将弘, 山田和夫, 神谷隆, 上田洋一：あと施工アンカーによる接合 面の固着強度に関する実験的研究，コンクリート工学年次論文集，第 28 巻, 第 2 号, pp.1111-1116, 2006

15) Ciampi, V, et al. : Analytical Model for Concrete Anchorages of Reinforcing Bars Under Generalized Excitations, Report No.UCB/EERC-82/23, Univ. of California, Berkeley, 1982.11

16) CEB/FIP Model Code 1990, First Draft, Bulletin d'Information, No.195, CEB, 1990.3

17）日本建築学会：鉄筋コンクリート造建物の耐震性能評価指針・同解説, 2004

18）福本晃治，清原俊彦，中野克彦，松崎育弘：接着系あと施工アンカーの 構造性能に関する実験研究, 日本建築学会大会学術講演梗概集, C-2, 構 造 IV, pp.719-720, 1998.7

（2013年 3 月 22 日原稿受理，2013年10月 3 日採用決定） 